Jusmal llmial

PFUR AT DE

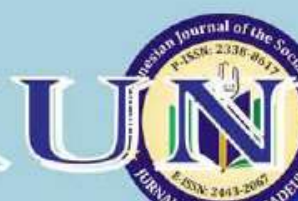

Vol. 5, No. 3, September 2017

$\int_{\substack{\text { Indrjesident } \\ \text { si in }}} 1$

sCAD Intependent Acreditatiou by 100 since 2014 $\bigodot$ Copernicus Publications

\section{JIP}

The Indonesian Journal of the Social Sciences www.journal.scadindependent.ors D01 Prefix Number; 10,26811
Csinta

INDEX COPERNICUS 


\title{
TEACHERS' READING CULTURE IN MADRASAH TSANAWIYAH ENVIRONMENT OF THE TARGET GRANT PROGRAM OF SCHOOL AND QUALITY COMPONENT ASSISTANCE
}

\author{
Amiruddin Siahaan \\ Universitas Islam Negeri Sumatera Utara, Indonesia \\ Email: amiruddin.siahaan@gmail.com
}

Received: July 12, 2017

Accepted: Sept 13, 2017

Published: Sept 28, 2017

Article Url: http://journal.scadindependent.org/index.php/jipeuradeun/article/view/169

\begin{abstract}
The low reading culture in teachers has an impact on the low ability and interest in writing scientific papers, of course; also have an impact on the stagnant level of education and teacher's rank. Nationally, most of the teacher's rank stops at group IV A. Because starting group IVA and above class increased, it requires the component of writing scientific papers, besides teaching component. The results showed that reading culture among Madrasah teachers who became the object of this research increased after the Grant Program of School Quality Component Assistance 3 Madrasah accreditation phase 2 of Indonesia Education Partnership to Australia. They are increasingly aware of the importance of improving the quality of self and improving the quality of Madrasah. Efforts are made to improve the culture of reading teachers, including 1) adding facilities for reading places, such as libraries and reading parks; 2) increasing the number of books collected in Madrasah, related to subjects and textbooks supporting subjects; 3) involving teachers in scientific forums, such as scientific paper competition, short stories, and seminars; 4). The principal as a leading coach for teachers provides motivation to teachers through teacher board meetings as well as directly, in order to increase interest in reading their teachers.
\end{abstract}

Keywords: Improvement, Culture, Reading, Teacher, Motivation 


\section{A. Introduction}

The condition of Indonesian teachers today is very worrisome, starting from low learning independence, timing difficulties, copy-paste culture, task titles, plagiarism, the work of what is "the origin so" and a low willingness to find the source of materials or references, this all happened Because of the low interest in reading the teachers. Reading interest is directly proportional to the level of educational progress of a nation. Reading is very important for the progress of a nation. Parameter quality of a nation can be seen from the condition of education. Education is always related to learning activities. Learning is always synonymous with reading activities because by reading will increase knowledge, attitude, and skills of a person. Education without reading like a body without a soul. The phenomenon of "intellectual unemployment" will not happen if society has a burning spirit of reading.

On the other hand from the low reading culture in teachers have an impact on the low ability and interest in writing scientific papers, of course, also affects the stagnant level of the teacher's rank. Nationally, most of the teacher's rank stops at group IV A. Because, starting group IVA above the class increase requires a component of the writing of scientific papers, in addition to the teaching component. As a result, in fact, out of about 2.6 million teachers only $0,87 \%$ of teachers are IVB, $0,07 \%$ for IVC group, and $0.02 \%$ for teacher IV D. It turns out that most teachers are not good at writing. Whereas the demands of certification must be able to compose scientific work. The problem, how to write a scientific paper if writing articles just less able. Logically, if used to write articles, let alone popular scientific articles, then writing a scientific paper was not a barrier anymore.

According to National Education Minister, Mohammad Nuh, teachers who have passed the certification generally do not show progress, both in terms of pedagogical, personality, professional, and social. According to the minister, teachers are only active ahead of certification, but after being declared qualified, their quality actually decreased (Kompas, 1 November 2010: 12).

Improving the quality and education quality is an integral part of the overall development of education, therefore it is the responsibility of 
all components of the nation, government and society to make it happen. The enactment of the Law of the Republic of Indonesia Number 14 The year 2005 on Teachers and Lecturers (UUGD) is one of the positive steps to bring Indonesian education in a quality and equitable direction. The implementation of the UUGD has spurred efforts to improve the quality of education in Indonesia, for example through improving the quality of human resources (HR), especially educators.

Wurianto (2008) states Emerson's statement that "If we encounter a man of rare intellect, we should ask him what books he reads." The free translation is something like this, if we meet someone with extraordinary intelligence, we should ask - guess what book he reads. Emerson's remarks were certainly not meaningless nonsense. Wherever place and time, people who have high intellectuals always hanged out with books. According to UNESCO, Tiras Indonesian newspaper's is only $2.8 \%$ of the population. Though the minimal index that decided by UNESCO is $10 \%$. By comparison, newspaper headlines in developed countries have reached $30 \%$. Still, according to UNESCO, Indonesia only publishes 9 titles of state books for every one million inhabitants. Whereas developed countries print 513 titles of books per one million inhabitants. How far is the range between the two? This should be a question of what causes this situation.

Based on the data and facts above we can conclude that if the education of Indonesia wants better then the quality and quality improvement of teachers must be improved, one way to improve the quality of teachers is to promote reading culture.

\section{B. Understanding Reading Culture}

Reading is seeing and understanding the contents of what is written with verbal or just in the heart (MoNE, 2013: 109). Klein, and friends in Rahim (2005: 3) suggests that the definition of reading includes: First, reading is a process. The point is that information from the text and knowledge possessed by the reader has a major role in shaping meaning. Secondly, reading is strategic. Effective readers use a variety of reading strategies that fit the text and context in order to construct meaning when reading. This strategy varies according to the type of text and the purpose 
of reading. Third, reading is interactive. The reader's engagement with the text depends on the context. People who love to read a useful text will meet some goals that want to achieve, the text read by someone must be easily readable (readable) so that the interaction between the reader and the text.

Reading is essentially a physical and psychological process. The process of a physical form of visual observing the writing and is a mechanical process in reading. The mechanical process continues with psychological processes in the form of thinking activities in processing information. The psychological process begins when the visual senses send the observed results to the writing to the center of consciousness through the nervous system. The process of decoding the sound images and their combinations is then identified, described, and given meaning. Decoding process takes place by involving the knowledge of the world in the schemata in the form of categorization of a number of knowledge and experience stored in the warehouse of memory.

The main purpose of reading is to find and obtain information, including content, to understand the meaning of reading. Meaning is closely related to purpose or intensive in reading. According to Anderson (2003) suggests the purpose of reading is as follows.

a. Reading to obtain details or facts (reading for details or facts). For example to know the discoveries that have been done by the character; What the character has made; What has happened to a special character, or to solve the problems made by the character.

b. Reading to get the main ideas (reading for main ideas). For example, to find out why it is a good topic and interesting, the problems contained in the story, what the character learned or experienced, and summarize things done by the character to achieve its goals.

c. Read to know the order or order, the organization of the story (reading for sequence or organization). Like discovering or knowing what happens to each part of the story, what happens first, second, and third / so on. Each stage is made to solve a problem, scenes, and scenes for dramatization.

d. Reading to conclude, reading inference (reading for inference). It's like discovering and knowing why the characters feel the way they 
do, what the character displays, the qualities of the characters that make them successful or fail.

e. Reading to the group, read to classify (reading to classify). For example, to discover and find out what is unusual, unnatural about a person's character, what is funny in the story, or whether the story is true or not true.

f. Read rate, read the evaluation (reading to evaluate). Like to find out if the character succeeds or lives with certain measurements, do we want to act like the way the character works in the story.

g. Reading to compare or contrast (reading to compare or contrast). This reading activity is done to discover how the character changes, how his life is different from the life we know, how the two stories have similarities, how the character resembles the reader.

\section{Research methods}

The approach used in this research is a qualitative approach, this approach is used because this research aims to find out how Private Madrasah Tsanawiyah Teachers of Target Grant Program of School and Quality Component 3 Madrasah Accreditation Phase 2 of The AustraliaIndonesia Education Partnership in Deli Serdang District reads the book so it is known to the culture They are in the reading. Therefore, to find the answers to the objectives of this study, the data are qualitatively considered effective as approaches.

According to McMillan and Schumacher (2001: 396), qualitative research is not just to understand the existing phenomenon, but it is also expected to generate theory or corroborate existing theories.The design of this study belongs to a case study. During the course of the research, the researchers sought unique cases of each event regarding how the Culture of Reading a Private Madrasah Tsanawiyah Teachers Target Grant Aid Program School and Quality Component 3 Madrasah Accreditation Phase 2 The Australia-Indonesia Education Partnership in Deli Serdang District.

Attempts to obtain data on Culture Reading of Private Madrasah Tsanawiyah Teachers Target Grants Program Grants School and Quality Component 3 Accreditation of Madrasah Pase 2 The Australia Indonesia 
Education Partnership in Deli Serdang District requires data sources that can answer many questions. Therefore, it is sought that those who have the capacity to provide information on the Culture of Reading the Private Madrasah Tsanawiyah Teachers Target Grant Aid Program School and Quality Component 3 Accreditation of Madrasah Phase 2 AustraliaIndonesia Education Partnership in Deli Serdang District. These various data sources are expected to provide the necessary data. After the data and information obtained, then developed in order to obtain data and information of various nature. In detail, it can be argued that the data sources in this study are: (1) teachers, (2) head of madrasah, (3) board of the foundation. (4) education supervisor, (5) madrasah committee.

Data collection was done by interview and observation technique. Both of these techniques are techniques that can collect the necessary data in answering various questions. Interviews and observations are conducted formally and informally so that the required data are met according to the needs of the study.

Based on the facts obtained in the field during the action to ensure the validity of data, the authors believe that there is no engineering by respondents in displaying attitudes or behaviors to match the desires of researchers. The researchers' confidence is due to unchanging what they say from the beginning to the end of data collection, as well as the ways in which they accept researchers within their environment.

\section{Research Findings and Discussion \\ 1. Teachers' reading culture in Madrasah}

The result of the research shows that after granted the program assistance of School Quality Component 3 Madrasah accreditation phase 2 of Indonesia-Australia Education Partnership in Deli Serdang District to madrasah in Deli Serdang area, there was a big change for the teachers. They are increasingly aware of the importance of self-improvement. One obvious improvement is the high level of reading culture among teachers in the madrassas that became the object of this study.

This shows that teachers are increasingly aware of the importance of reading for them. Dalman (2013: 5-6) explains that by reading we can know 
the whole world and our thinking patterns will develop. By reading often, a person can master many words and learn various sentence models, furthermore, he can improve his ability to absorb concepts and to understand what is written: "between line by line" (understand what is implied).

This is in line with the opinion of Sutomo (2003) states that the main consequences arising from a society that has a low reading culture are an unproductive society. The unproductive community as a result of 3 (three) factors namely: difficult communication, cannot be innovation, difficult transfer and use science and technology. These three factors are caused by the core problem that is in the community concerned reading and learning has not become a culture. And not cultivated reading and learning in our society is caused by 3 (three) things namely: less effective education system, the community is not aware, culture is less conducive.

Based on law number 43 the year 2007 about libraries that culture love to read become the responsibility of the family, educational unit (school), society, and government. As the law on the 48th section of the library follows.

a. The culture of reading is done through family, educational unit, and society. The culture of reading literature on the family as referred to in paragraph (1) is facilitated by the Government and local government through cheap and quality books.

b. The culture of reading in the educational unit referred to in paragraph (1) shall be done by developing and utilizing the library as a learning process.

c. The reading culture of the community as referred to in paragraph (1) shall be conducted through the provision of library facilities in public places that are easy to reach, cheap and quality.

Blanton et al and Irwin (Farida Rahim, 2008: 11) describe several reading objectives as follows:
a. Fun;
b. Refine a specific strategy;
c. Use a specific strategy;
d. Updating knowledge about a topic;
e. Linking new information with information it already knows; 
f. Obtain information for oral or written reports;

g. Confirm or reject the prediction;

h. Display an experiment or apply an information obtained from a text in some other way and learn about the structure of the text, answering specific questions.

\section{Efforts are made to improve the teachers' reading culture}

The results show that there are several efforts made to improve the reading culture in schools, including 1) adding facilities for reading places, such as libraries and reading parks; 2) increase the number of existing book collections of the school, related to the subject and the supporting textbooks; 3) include teachers in scientific forums, such as scientific paper competition, short stories, and seminars; 4). The principal as the leading coach for teachers should continue to provide teacherteacher motivation through teacher board meetings as well as directly, in order to increase interest in reading his teachers.

According to N.S Sutarno (2003), there are several factors that can encourage the rise of interest in reading the community. These factors are:

a. High curiosity over facts, theories, principles, knowledge, and information.

b. The state of the physical environment is adequate, in the sense of the availability of interesting reading materials, quality, and variety

c. Conducive social environment, meaning the climate can be used to read.

d. Information thirst, curiosity, especially the actual.

e. Living principle that reading is a spiritual need.

The purpose of fostering reading interest is to create a reading society (reading society), learning community (learning society) in order to educate the nation's life that is characterized by the creation of qualified human resources (HR) as a tool of national development towards civil society. (IdrisKamah, 2002: 19). The target of the guidance aimed at the community as a whole in the various layers that exist include all age, sex, type and level of education, type of work or profession, and so on. 
According to Frans M. Parera in IdrisKamah (2002: 19-20), the policy of developing public interest is directed through five channels, namely: (1) Guidance through household and family lines, (2) Guidance through community and environment (4) Guidance through institutional channels (office), and (5) Guidance through functional agency channels (national libraries, provincial libraries and district / municipal libraries). Furthermore, in determining the pattern of guidance interest and reading habit no longer think of family, community, and government, but focusing attention on the special guidance on the individuals and the main target is children under five and teenagers, from children aged 1 (one) to 18 (eighteen years). The pattern of interest and reading habit can be seen from the following picture.

\section{Picture 1}

Pattern of Interests and Reading Habits

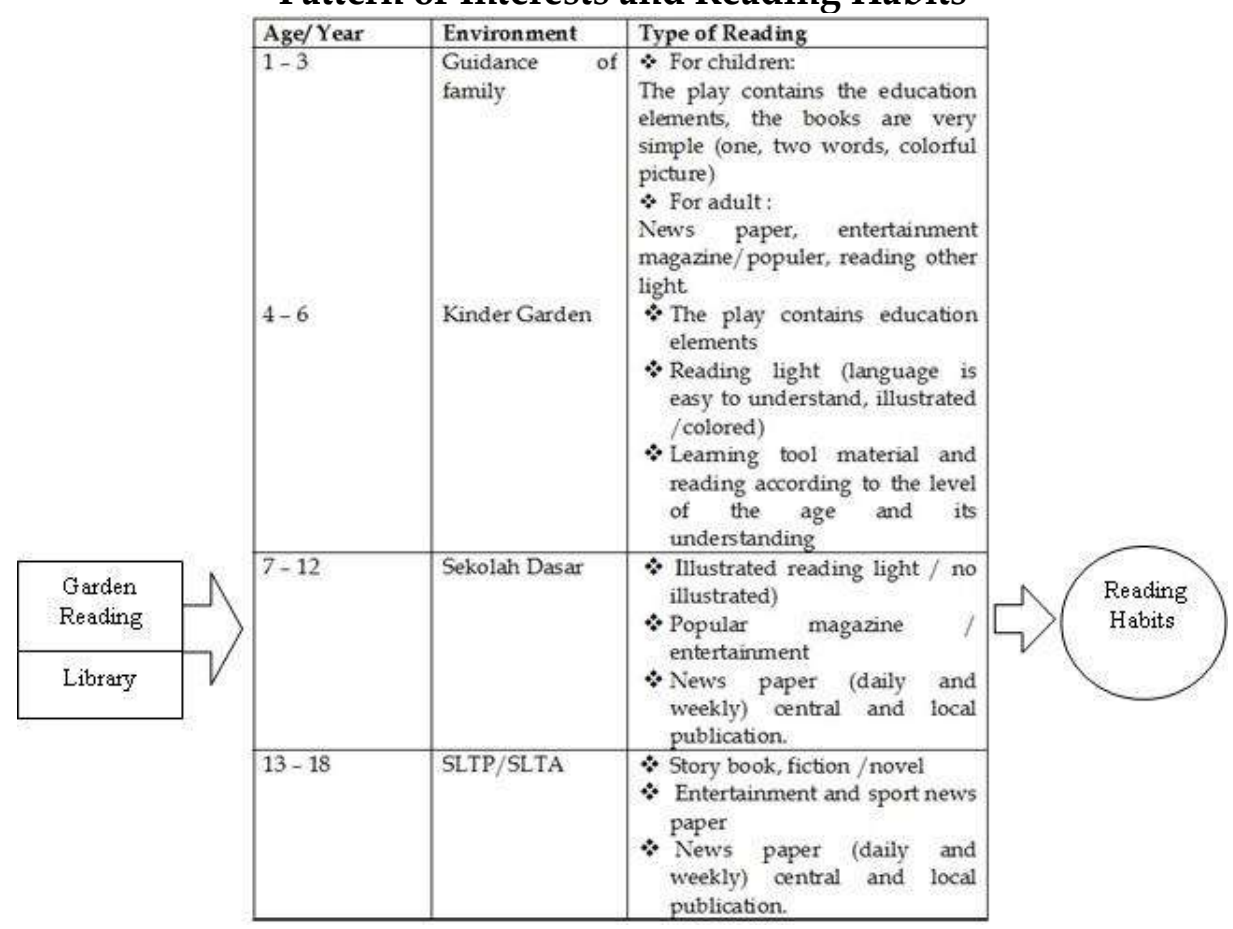

From the above explanation clearly, shows the relationship between reading interest with the collection or reading material. To increase the reading interest of the community, the library is needed as a means to provide various reading materials needed by the community. 
The picture below explains the relationship between taste, reading interest and collection (reading material) to create a reading culture.

Figure 2

The process of creating a reading culture

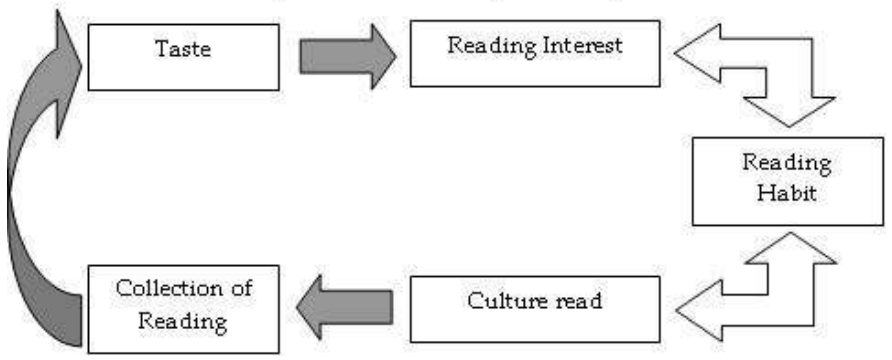

According to Suprihati, as followed by Idris Kamah (2002: 10), there are several strategies that must be done for the development of reading interest of the community, namely; (1) Encourage and facilitate the growth of libraries and reading parks, (2) Development and development of library and reading interest of the community implemented comprehensively, effectively and efficiently with the use of technological developments, (3) Guidance and development of reading interest of the community implemented in a planned, Gradually and continuously, (4) Guidance and development of library and reading interest with existing resource utilization, (5) Guidance and development of library and reading interest implemented in an integrated manner/ cooperation with local government and related institutions, (6) Community empowerment by strengthening Infrastructure, while the government as a catalyst/ mobilizer, (7) Implement the evaluation of library empowerment as a suggestion of the development of community reading interest in a coordinated manner between central government, provision, district/ city, (8) Encourage the formation and promotion of reading interest society in province, regency/ city, and (9) Encourage the development of professions in the field of books and other reading facilities.

\section{Obstacles in an effort to improve the reading culture of teachers}

The results showed there are some things that cause a lack of interest in reading the teacher namely: 1) the teacher has not considered reading is the need for satisfaction or essential items such as clothing or 
meanwhile needs just a need to find something that needs only; 2) lack of passion and awareness of reading teachers to improve insights and useful things; 3) lack of support facilities that motivated teachers to read both in school and outside school; 4) Lack of promotion from various parties to increase reading interest for teachers both government and other private institutions; And 5) The wide variety of entertainment, games, TV shows and entertainment venues to spend time so as to distract teachers to read.

Read culture will not be created if there is no interest in reading that grows in a person. There are several factors that cause low interest in reading, including:

1. The rapid flow of entertainment through electronic media such as television. Today's technology is getting more sophisticated and kids tend to be addicted to a variety of technology-based games like video games, PlayStation, and more.

2. Indonesian culture of both teens and parents spend more time chatting than reading.

3. The strength of the outer attraction is very strong tempting tease young people like playing the band, hanging out at the mall, watching movies, and so forth.

4. The relatively low level of people's income or the Indonesian economy can affect purchasing power or priority needs. Books are not one of the primary needs, only fulfilled when their daily needs are met.

5. Lack of awareness of the importance of reading. The still low awareness of Indonesian families on the importance of reading for children. For example, the lack of attention of parents in the use of leisure time can have an impact on reading interest since childhood.

6. At some level, the ability of the people to speak Indonesian is still an issue as people who are still illiterate or who do not understand Indonesian

7. An educational system that emphasizes the transfer of knowledge from teacher to student. The position of the teacher as the main 
source of information and students as recipients of knowledge with the assumption of a gift or something purchased.

8. Unavailability of reading material and facilities. Quality books are still rare because publishers see market share that prefers light reading like comics, novels, or even pornographic magazines

9. Lack of improved library quality in terms of collection and service system that can also give a negative influence on the development of reading interest.For example, the number of libraries with inadequate conditions and minimal librarian resources.

10. Mental children and family/community environment that does not support.

There are several factors that can encourage the rise of interest in reading the community. These factors are; (1) high curiosity over facts, theories, principles, knowledge and information, (2) the state of adequate physical environments, in the sense that the availability of interesting, qualified and diverse reading materials, (3) conducive social environment, The existence of a climate that is always used at a certain time to read, (4) the thirst of information, curiosity, especially the actual, and (5) live principle that reading is a spiritual need.

Interest in reading is the potential that already exists in each person that is contained in the human brain since the construct of the period (fertilization) in the mother's womb. That potential will grow and develop after being born into the world, depending on the available thrust factor, the circumstances, and the living environment of the prevailing system. According to Baderi (2005: 5), there are at least five factors that influence the reading interest of a person, namely; (1) Encouragement from within, (2) Family Environment, (3) Community environment, (4) School environment/ education, and (5) National education system.

While Bunanta (2004: 232) states that interest in reading is mainly highly determined by:

1. Family environment factors in this case such as family reading habits in the home environment. 
2. Educational factors and curriculum in schools that are less conducive.

3. Infrastructure factors in society are less supportive of increasing interest in reading the community.

4. As well as the factor of existence and affordability of reading material

While it is understood that there is a relationship between reading interest with the speed of reading comprehension for learners. The results of Guritnaningsih A Santoso research suggests that reading interest and reading comprehension can be improved through information processing approach. The study was conducted on 180 elementary students in DKI Jakarta and West Java since October 1999. The result, among others, students have a low ability in understanding the sentence so as not to be able to capture the main idea of reading.

This is mainly due to low interest in reading school students. (Santoso: 2000). Ki Supriyoko (2004), stated: "Theoretically there is a positive relationship between reading interest with reading habit and reading ability. The low public interest in reading makes reading habits low, and this low reading habit makes reading ability low. That's what's happening to our society right now. "To overcome this backwardness is needed early education, from the family environment, schools, and society. Education in the family is a key driver of reading interest. Reading interest should be installed by parents since childhood. The easiest way is to tell stories through storybooks. After a child can read, it is hoped they will try to know the contents of the reading without waiting to be told. In turn, they will be interested to read.

The next factor that is also very influential in education in schools and neighborhoods. Education in schools encourages children to read because of the demands of the lesson. Meanwhile, the environment also encourages reading interest because a child performs activities according to the people around him. Children become diligent in reading if the people around them do it. 


\section{E. Conclusion}

The culture of reading among the teachers in the madrassas are the object of research is increasing as it provides Grant Assistance Program School Quality Component 3 Madrasah Accreditation Phase 2 Australia Indonesia Education Partnership in Deli Serdang to the madrasah that exists in Deli Serdang area. They are increasingly aware of the importance of improving the quality of self and improving the quality of Madrasah.

Efforts are being made to improve the culture of reading teacher at MTs neighborhood grant program targets Private School Quality Component 3 phase 2 accreditation Madrasah education partnership Indonesia Australia in Deli Serdang are: 1) to expand its facilities for a place to read, such as the library and read ; 2) increase the number of existing book collections of the school, related to the subject and the supporting textbooks; 3) include teachers in scientific forums, such as scientific paper competition, short stories, and seminars; 4). The principal as the leading coach for teachers should continue to provide teacherteacher motivation through teacher board meetings as well as directly, in order to increase interest in reading his teachers.

Obstacles in improving the reading culture teacher at MTs neighborhood grant program targets Private School Quality Component 3 phase 2 accreditation Madrasah education partnership Indonesia Australia in Deli Serdang namely: 1) teachers not think of reading a satisfying needs or important subjects such as The need for clothing or but just a need to find something that need only; 2) lack of passion and awareness of reading teachers to improve insights and useful things; 3 ) lack of support facilities that motivated teachers to read both in school and outside school; 4) Lack of promotion from various parties to increase reading interest for teachers both government and other private institutions; And 5) The wide variety of entertainment, games, tv shows and entertainment venues to spend time so as to distract teachers to read. 
Amiruddin Siahaan

\section{Bibliography}

Anderson, N. (2003). "Reading" in Practical Language Teaching Reading. David Nunan, (ed.). New York: McGrow Hall.

Baderi, Athaillah. (2005). Teknik Pemasyarakatan Perpustakaan dan Pembinaan Minat Baca", Training Material Extension and Interests Fan Interest.

Bunanta, Murti. (2004). Mendongeng dan Minat Membaca. Jakarta: Pustaka Tangga.

Dalman. (2013). Keterampilan Membaca. Jakarta: PT. Raja Grafindo Persada.

Depatermen Pendidikan Nasional. (2012). Keterampilan Membaca. Jakarta: Pusat Pengembangan Profesi Guru Depdiknas.

Depatermen Pendidikan Nasional. (2013). Kamus Besar Bahasa. Jakarta: Depdiknas.

Ghazalba, Sidi. (1998). Pengantar Kebudayaan Sebagai Ilmu. Jakarta: Pustaka Antara.

Kamah, Idris, (et.al.). (2002). Pedoman Pembinaan Minat Baca. Jakarta: Perpustakaan Nasional RI.

McMillan, J. H., \& Schumacher, S. (2001). Research in education: A conceptual introduction (5th ed.). New York: Longman.

Mulyana, Deddy \& Rachmat, J. (2006). Komunikasi Antarbudaya: Panduan Berkomunikasi dengan Orang-Orang Berbeda Budaya. Bandung:Remaja Rosdakarya.

Nufiar, N., \& Idris, S. (2016). Teacher Competence Test of Islamic Primary Teachers Education in State Islamic Primary Schools (MIN) of Pidie Regency. Jurnal Ilmiah Peuradeun, 4(3), 309-320.

Nurrahmad, Hadi. (2008). Membangun Budaya Membaca di Lingkungan Perguruan Tinggi Sebagai Upaya Meningkatkan Intelektualitas Mahasiswa. Diarsipkan oleh PLS UM untuk Imadiklus.com.

Patimah, S. (2015). Pengaruh Rekrutmen dan Seleksi Terhadap Kinerja Kepala Madrasah Ibtidaiyah Negeri (MIN) Sekota Bandar Lampung. Jurnal Ilmiah Peuradeun, 3(1), 165-190.

Rachmawati, Dawn. (2008). Dunia di Balik Kata (Pintar Membaca). Yogyakarta: Grtra Aji Parama. 
Rahim, F. (2005). Pengajaran Membaca di Sekolah Dasar. Jakarta: Bumi Aksara Soekanto, S. (2013). Sosiologi Suatu Pengantar. Jakarta: Raja Grafindo Persada.

Son, Masri Sareb. R. (2008). Growing Reading Interest Early. Index. Jakarta.

Sutarno, N.S. (2003). Perpustakaan dan Masyarakat. Jakarta: Yayasan Obor Indonesia.

Sutomo, Sumengen. (2003). Membangun Bangsa Budaya Baca dan Belajar 100 Tahun Mendatang. Jakarta: Yayasan Bangun Indonesia.

Tarigan, H.G. (2008). Membaca: Sebagai Suatu Keterampilan Berbahasa. Bandung: Angkasa.

Usman, M. (2015). Teaching Model of Learning English Writing at University. Jurnal Ilmiah Peuradeun, 3(3), 441-450. 